\title{
Bilateral Panner's disease in sickle cell anaemia: Case report
}

T.W. King, MA (Cantab), BM BCh (Oxon), MRCS (Eng), H.C. Le Quesne, BSc (Hons) and A.R. Norrish, BSc (Hons), MB BChir (Cantab), PhD (Cantab), FRCS (Tr\&Orth), Tropical Surgery Research and Training Cetre, Beit Cure Hospital, P.O. Box 36961, Lusaka, Zambia

Correspondence and reprint requests to:

Dr. T.W. King, Tropical Surgery Research and Training Cetre, Beit Cure Hospital, P.O. Box 36961, Lusaka, Zambia, Email: tking@doctors.org.uk

\section{Summary}

Avascular necrosis is common in sickle cell disease in various vulnerable areas such as in the femoral or humeral heads. Panner's disease however is described as avascular necrosis of the capitellum, which commonly occurs in a younger age group. It is a pathological process believed to be caused by interference in the blood supply to the growing capitellar epiphysis. A 17 year old boy with sickle cell disease presented with pain on pronation and supination of both elbows, particularly on the lateral side. These movements were restricted in both elbows. Plain radiograph of his elbows showed fragmentation of the capitellum with signs of revascularisation. We have performed a thorough literature search and have not found other reported cases of Panner's avascular necrosis of the capitellum in association with sickle cell disease. We conclude that Panner's disease is a possible complication of sickle cell anaemia.

\section{Introduction}

Sickle cell disease is the most frequent haemoglobinopathy in the world (1). The cause is a point mutation in the allele that codes for the beta chain of haemoglobin with a substitution (valine for glutamic acid at position 6). The most common types of sickle cell disease are HbSS, HbSC and HbS-beta thalassemia (2). Other rarer diseases include SD Punjab, SO Arab, S Lepore and SE disease. The gene is autosomal co-dominant and as such, patients may also be carriers; $\mathrm{HbAS}$ or exhibit the other subtypes. Sickle cell trait (HbAS) is particularly common in equatorial Africa with a prevalence of $10-40 \%$. The Baamba tribe in Western Uganda has a $45 \%$ carrier rate (1). People with sickle cell trait do not usually have symptoms of the disease although care needs to be taken when experiencing low oxygen tensions such as in an unpressurised aircraft cabin or whilst scuba diving.

The correlation between prevalence of the sickle cell gene and endemic malaria relates to the fact that sickle cell trait confers some resistance to Falciparum malaria in a critical period of early childhood (3). Sickle cell anaemia confers no resistance to malaria and indeed is a major cause of death in these patients (1).

Sickle cell disease is characterised by haemolytic anaemia crises and cardiopulmonary, digestive, neurological, ocular and osteo-articular manifestations (3). Osteo-articular complications are frequent and may compromise growth (4). The reason for these crises relates to the change in shape of the red blood cell as it is deoxygenated in the tissues. As oxygen is removed from the HbS molecules, they tend to crystallise and precipitate out of solution which distorts the shape of the cell. The sickle shaped red blood cell increases resistance in capillaries and can precipitate thrombosis, particularly in the presence of other predisposing features such as stasis or hypothermia.

Orthopaedic complications of sickle cell disease are almost inevitable. Osteomyelitis and septic arthritis are more common in affected individuals (5). Staphylococcus aureus is the 
most common organism but Salmonella spp. is overrepresented (6). Pathological fractures may occur in diseased bone. Dactylitis affects 20$50 \%$ of individuals, characteristically between six months and two years of age and is almost always self-limiting (7). Thrombotic and infective complications after surgery must be anticipated and appropriate prophylactic steps taken.

Avascular orthopaedic complications of sicklecell disease have been widely documented. Vulnerable sites for infarction and subsequent avascular necrosis include the humeral head $(8)$, femoral head $(9,10)$ and vertebrae $(11)$.

Panner's disease is a focal, localised lesion of the subchondral bone of the capitellum and its overlying articular cartilage. It is also known as osteochondrosis of the capitellum of the distal humerus. Firstdescribed by Pannerin1927 (12) and 1929 (13), the disease demonstrates radiographic changes in the epiphysis of the humeral capitellum resembling those of Perthes' disease of the hip. Characteristically, the ossification centre is disordered with degeneration and necrosis of the capitellum. However, in contrast with the natural history of Perthes' disease, this is followed by regeneration of the ossific nucleus (14).

As with most osteochondroses, the aetiology of Panner's disease is uncertain, but it is believed to be caused by an interference in blood supply to growing epiphysis. In patients under 20 years of age, the capitellum is only supplied by end arteries entering posteriorly $(15,16)$.

The natural history of this process is benign, with restoration of normal appearance, size, and contour of the capitellum (17). Residual deformity and collapse are rare. It is sometimes misdiagnosed as osteochondritis dessicans
(OCD). The benign natural history of Panner's disease in contrast to that of OCD makes recognition of this entity important (18).

Panner's disease usually occurs in the dominant elbow of boys between 5 and 12 years of age. Precipitating causes are said to include, chronic repetitive trauma, congenital and hereditary factors, fat embolism, and endocrine disturbances (15). A literature search revealed no reports of previous cases associated with sickle cell disease.

\section{Case report}

A 17 year old male presented to the outpatient department with unilateral genu valgus and sickle cell anaemia (type HbSC, by testing using 'sickle cell spot test' and on clinical grounds, electrophoresis was not available). On further questioning he gave a four year history of bilateral elbow pain and restriction of pronation and supination, starting at age 11 years. He gave no history of repetitive trauma or unusual throwing activities nor any family history of similar symptoms. His symptoms were now resolving, but he still felt he had some residual limitation in extension of elbow.

Examination revealed mild tenderness over the capitellum and 10 degrees restriction to full extension of the elbow bilaterally. Pronation and supination of both elbows hitherto painful was however normal. Blood tests revealed no evidence of endocrine abnormalities. Plain radiographs of the child are shown below and demonstrate the disease approaching the resolution phase, with only minor changes to the contour of the capitellum (Figure 1).

Figure 1: Plain radiographs showing minor contour deformities (arrows) of the capitellum

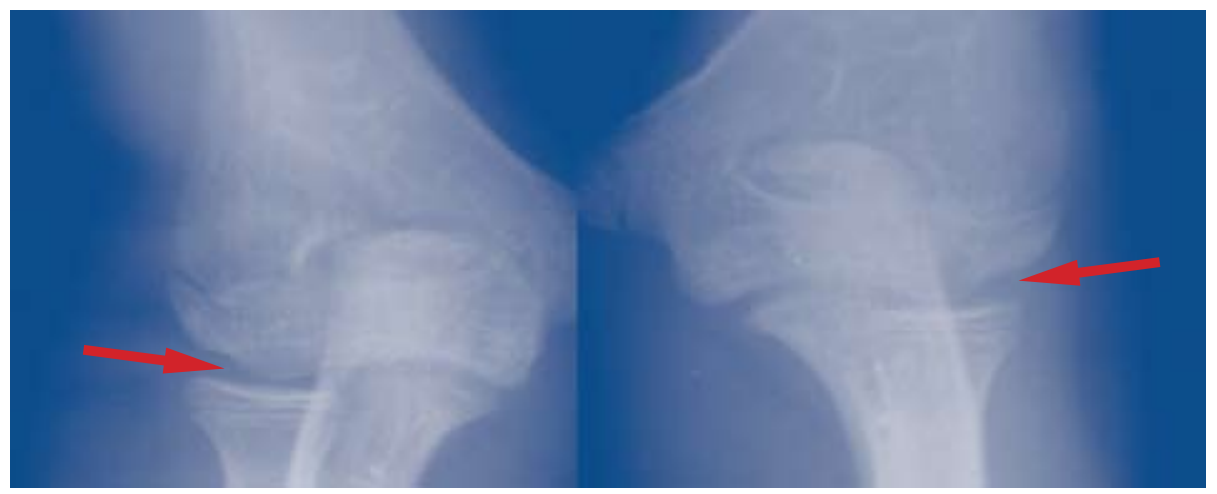




\section{Conclusion}

Given the nature of the patient's symptoms and almost full resolution of both clinical symptoms and radiological features, it seems a diagnosis of bilateral Panner's disease is justified. The growing capitellum clearly has a vulnerable vascular supply and hence is susceptible to avascular necrosis in the same way as the femoral or humeral heads. The documented association of avascular necrosis of the femoral and humeral heads with sickle cell disease makes a link with Panner's disease highly probable.

This is the first reported case to the best of our knowledge of such an association between sickle cell disease and Panner's disease and as such further cases need to be found to establish the causal association.

\section{References}

1. World Health Organization fifty-ninth World Health Assembly A59/9. Prevalence of sickle-cell anaemia. http://www.who.int/gb/ebwha/pdf_files/WHA59/A59_9en.pdf

2. Golding J.S.R., MacIver J.E. and Went L.N. The bone changes in sickle cell anaemia and its genetic variants. J. Bone Joint Surg. Brit. 1959; 41-B (4): 711.

3. Stuart M.J. and Nagel R.L. Sickle-cell disease. The Lancet, Volume 364, Issue 9442, 9 October 2004-15 October 2004, Pages 1343-1360

4. Bennett O.M. and Namnyak S.S. Bone and joint manifestations of sickle cell anaemia. J. Bone Joint Surg. Brit. 1990; 72-B: 494-499.

5. Lavy C.B.D., Thyoka M. and Pitani A.D. Clinical features and microbiology in 204 cases of septic arthritis in Malawian children. J. Bone Joint Surg. Brit. 2005; 87-B: 1545-1548.
6. Ebrahim G.J. and Grech P. Salmonella osteomyelitis in infants. J. Bone Joint Surg. Brit. 1966; 48-B: 350-353.

7. Babhulkar S.S., Pande K. and Babhulkar S. The handfoot syndrome in sickle-cell haemoglobinopathy. J. Bone Joint Surg. Brit. 1995; 77-B: 310-312.

8. Milner P.F., Kraus A.P., Sebes J.I., Sleeper L.A. and Dukes K.A. Osteonecrosis of the humeral head in sickle cell disease. Clin-Orthop. 1993; (289): 136-143.

9. Ware H.E., Brooks A.P., Toye R. and Berney S.I. Sickle cell disease and silent avascular necrosis of the hip. J. Bone Joint Surg. Brit. 1991; 73-B: 947-949.

10. Iwegbu C.G. and Fleming A.F. Avascular necrosis of the femoral head in sickle-cell disease. A series from the Guinea Savannah of Nigeria. J. Bone Joint Surg. Brit. 1985; 67-B: 29-32.

11. Rexroad J.T., et al. "Fish" or "fish mouth" vertebrae? Amer. J. Roentgenol. 2003; 181: 886-887.

12. Panner H.J. An affection of the capitulum humeri resembling calve-perthes' disease of the hip. Acta. Radiologica. 1927; 8: 617.

13. Panner H.J. A peculiar affection of the capitulum humeri, resembling calve-perthes' disease of the hip. Acta. Radiologica. 1929; 10: 234.

14. Hughes P.E. and Paletta G.A. Little leaguer's elbow, medial epicondyle injury, and osteochondritis dissecans. Sports Medicine \& Arthroscopy Review. The Elbow. 2003; 11(1): 30-39.

15. Edited by Karas S. Panner's disease / osteochondrosis. Wheeless' textbook of orthopaedics. http://www. wheelessonline.com/ortho/panners_disease_osteochondrosis.

16. Ruch D.S. and Poehling G.G. Arthroscopic treatment of Panner's disease. Clin. Sports Med. 1991; 10: 629-636.

17. Sty J.R. and Boedecker R. Panner's disease (osteonecrosis of the capitellum). Clin. Nuclear Med. 1978; 3(3): 117.

18. Wiesler E.R. and Poehling G.G. Osteochondritis dissecans of the capitellum. Techniques in Shoulder and Elbow Surgery. 2001; 2(2): 131-138. 